\title{
CONVERTING TO INCLUSIVE ONLINE FLIPPED CLASSROOMS IN RESPONSE TO COVID-19 LOCKDOWN
}

\author{
A. Gerber* \\ http://orcid.org/0000-0003-1743-8167
}

\section{S. Eybers*}

http://orcid.org/0000-0002-0545-3688

*Department of Informatics

University of Pretoria

Pretoria, South Africa

\section{ABSTRACT}

The global Covid-19 pandemic caused havoc in higher education teaching routines and several residential institutions encouraged instructors to convert existing modules to flipped classrooms as part of an online, blended learning strategy. Even though this seems a reasonable request, instructors straightaway encountered challenges which include a vague concept of what an online flipped classroom entails within a higher education context, a lack of guidelines for converting an existing module, facilitating learner engagement as well as unique challenges for inclusion of all learners in a digitally divided developing country in Covid-19 lockdown. In order to respond, we embarked on a study to identify the distinguishing characteristics of flipped classrooms to understand the as-is and to-be scenarios using a systematic literature review. The characteristics were used to develop of design considerations to convert to an online flipped classroom for higher education taking our diverse learner profiles into account. We subsequently converted a short module in an information systems department and shortly report on our experience.

Keywords: inclusive online flipped classrooms

\section{INTRODUCTION}

The flipped classroom approach has been around for some decades and received noteworthy attention in higher education (Gaughan 2014; Green, Banas, and Perkins 2017; O'Flaherty and Phillips 2015). Recent interest in flipped classrooms is also due to the disruption caused by the Covid-19 pandemic. Lockdown restrictions prohibit physical contact lectures, and the subsequent move to online flipped classrooms as part of a blended learning strategy seems a logical consequence (Gower 2019). Flipped classrooms are associated with online learning materials, online preparation, blended learning, online learning, discussion classes, studentcentred learning and active participation (Green et al. 2017; Reidsema et al. 2017). However, 
when we embarked on the initiative to convert existing traditional modules to online flipped classrooms, several challenges immediately emerged. Preparation materials were provided online, but because instructors have limited influence, students did not know what to expect and did not prepare for class. Discussion classes were therefore not optimal. We started an investigation into flipped classrooms and found that most of these challenges are echoed in literature (Gilboy, Heinerichs, and Pazzaglia 2015; Li and Dan 2015; May and Elder 2018; Palloff and Pratt 2013; Pedrotti and Nistor 2019). We also found that literature on flipped classrooms was vague on what exactly a flipped classroom entails and how to develop one, especially of it has to be completely online. Inequality and the digital divide were also pushed into the limelight since sufficient mobile data and bandwidth is necessary to participate in online classes. All these concerns provided the motivation for this study namely the need to understand exactly how the to-be online flipped classroom differs from the as-is traditional teaching approaches, and how to subsequently design inclusive online flipped classrooms.

Our study consisted of two parts with two contributions. We adopted a systematic literature review (SLR) to identify the distinguishing characteristics of the flipped classroom approach. We then used the characteristics as well as the profiles of our learners to develop design considerations for inclusive online flipped classrooms specifically for circumstances given the Covid-19 pandemic.

The remainder of this article is structured as follow: Section 2 provides background and Section 3 describes the adopted systematic literature review (SLR) method. Sections 4 and 5 describe the two contributions namely firstly, the fundamental distinguishing characteristics of flipped classrooms followed by design considerations for inclusive online flipped classroom development. Section 6 reports on our findings and Section 7 concludes.

\section{BACKGROUND: THE FLIPPED CLASSROOM}

The term flipped classroom emerged in Google Trends around 2010 (Figure 1), and it was rapidly adopted to such an extent that a Google Scholar search returned more than 74000 results. However, literature and discussions on flipped classroom are fragmented and often inconsistent. For example, the general definition is that a flipped (or inverted) classroom delivers instructional content outside of the classroom and it moves activities that were traditionally considered homework into the classroom. However, most traditional teaching approaches also expect students to prepare for class prior to class so that class contact time could be used for more advanced teaching. Not surprisingly these discussions claim that a flipped classroom is just a popular word for what has always been good teaching (Akçayır and Akçayır 2018; Lin et al. 2019; Seedoyal-Seereekissoon 2018). Many resources focus on flipped 
classrooms within schools, and initiatives such as FLIP (the Flipped Learning Network) propose approaches such as the 4 pillars of FLIP (FLIP 2014), and thus create satellite communities with a specific focus not necessarily consistent with mainstream academic literature on the topic. Flipped classrooms are associated with blended learning, which is an umbrella term for the use of technology for out-of-class learning in order to support face-toface learning (Chiang 2017). Several publications assume that any availability of content videos that students can watch constitute flipped classrooms (Heijstra and Sigurðardóttir 2018; Roehl, Reddy, and Shannon 2013), even massive open online modules (MOOCs) that are online teaching environments that incorporates user forums or social media discussions to support student interactions (Bralić and Divjak 2018; Sari, Bonk, and Zhu 2020).

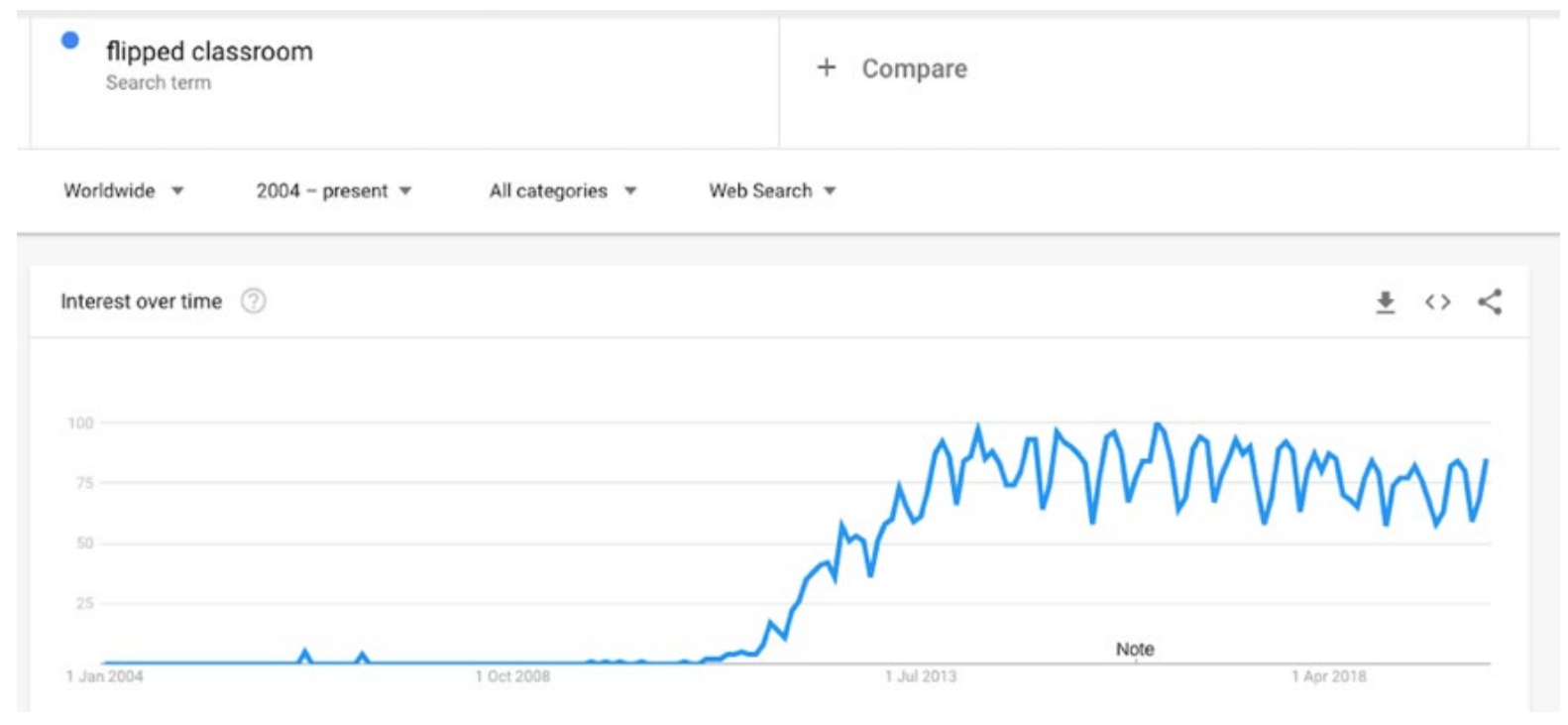

Figure 1: Google Trends on the "flipped classroom" term (executed on 18/2/2020). Numbers represent search interest relative to the highest point on the chart. A value of 100 is the all-time peak popularity of the term.

It was not possible to effectively convert traditional classrooms to flipped online classrooms without understanding the characteristics that distinguish them from traditional teaching, and we therefore adopted a systematic literature review (SLR) approach as presented in the next section.

\section{METHOD: SYSTEMATIC LITERATURE REVIEW (SLR)}

In order to execute the SLR on a manageable data set, we selected literature on flipped classrooms in higher education, specifically within the context of computing disciplines. An initial Google Scholar search returned more than 74000 results and provided an overview of scholarly resources available. Adding a date range restriction of 2015-2020, still returned more 
than 19000 results and we subsequently adopted a SLR method based on Kitchenham (2004) as depicted in Figure 2.

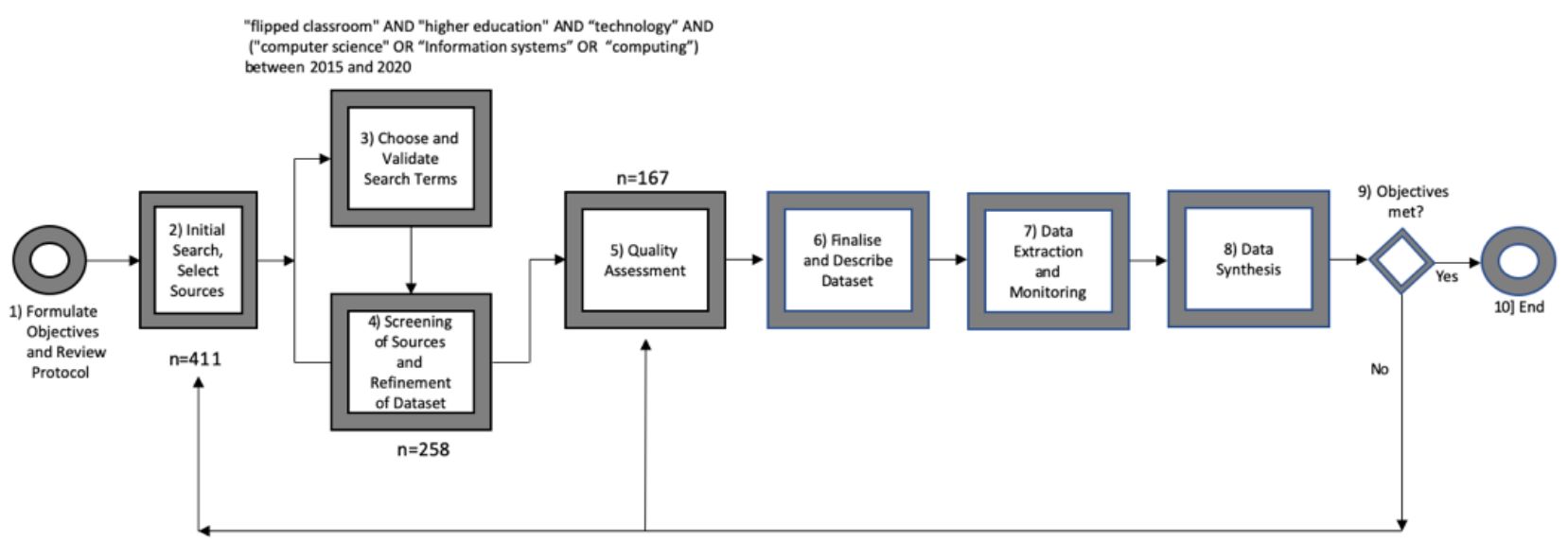

Figure 2: SLR Method adopted for this study

The adopted method is described according to the numbered steps in Figure 2:

1) Formulate objectives and review protocol: The objective of the SLR is to identify distinguishing characteristics that support design considerations for flipped classrooms. The review protocol is elaborated on under steps 2 and 3.

2) Initial search and selection of sources: The Google Scholar results were used to determine relevant databases: IEEE, Springer, Taylor and Francis, Sage, Science Direct and Scopus repositories. We included significant peer-reviewed and cited publications from Google Scholar.

3) Choose and validate search terms: We executed an advanced search on all the selected libraries with the keywords "flipped classroom" AND "higher education" AND ("information systems" OR “computer science" OR "computing") between 2015 and 2020. The resulting dataset: $n=411$ comprising of Google Scholar (44) + IEEE (71) + Taylor \& Francis (37) + Sage (35) + Science Direct (107) + Scopus (117).

4) Screening of sources and refinement of dataset: We removed all duplicates, all nonEnglish papers and most publications on flipped classrooms in schools or subjects not relevant to STEM or IS e.g., language modules. Some of these publications were included if they contained core information about flipped classroom characteristics or design: resulting dataset $\mathrm{n}=258$.

5) Quality Assessment: Removed most conference publications, publications that just discussed a technology intervention or MOOCs, as well as publications that did not 
include distinguishing characteristics left a dataset with $n=167 .{ }^{1}$ Carefully selected exceptions were included such as a publication on factors that influence the effectiveness of flipped classroom teaching (Fraga and Harmon 2014).

6) Finalise and describe dataset: Publications were peer-reviewed and published in journals between 2015 and 2020. Exceptions included relevant data.

7) Data extraction and monitoring, and

8) Data synthesis: This activity identified distinguishing characteristics that support design considerations for flipped classrooms in higher education. The search terms and exclusion criteria reduced the context mainly to computing disciplines. Each publication was scrutinised with the distinct intent to extract distinguishing characteristics, i.e., what makes a flipped classroom different from the way in which we teach computing lectures in a residential higher education classroom environment.

\section{DISTINGUISHING CHARACTERISTICS OF FLIPPED CLASSROOMS IN HIGHER EDUCATION}

In this section we document the first part of the research study namely the results of the SLR identifying the distinguishing characteristics of flipped classrooms.

\section{What is a flipped classroom?}

Several publications in our dataset defined a flipped classroom as the "flipping" or "inverting" of activities, for instance, Fraga and Harmon (2014) who claimed that a flipped classroom is a model of instruction where "what generally occurs during class time, such as lectures and demonstrations, occurs at home, and assignments typically completed out of class occur during class". Variations of the definition insist on the inclusion of technology e.g., Chan, Lam, and Foo Ng (2018): "Flipped classroom is a technology-supported pedagogical innovation ...". Karabatak and Polat (2019) define a flipped classroom as a blended learning approach where learners access content outside school with the help of asynchronous resources (module videos and articles, various electronic data sources, images and presentations. Kay, MacDonald and DiGiuseppe (2019) define a flipped classroom as learners being given multimedia videos before class and that class-time is used for differentiated instruction where students "complete learning exercises during class, with the instructor acting as coach, mentor, or guide".

Abeysekera and Dawson (2015) analyzed flipped classrooms and provide one of the most thorough definitions, namely that

"the flipped classroom is a set of pedagogical approaches that: 
(1) move most information-transmission teaching out of class;

(2) use class time for learning activities that are active and social; and

(3) require students to complete pre- and/or post-class activities to fully benefit from in class work."

The SLR extracted the following characteristics:

- $\quad$ Flipped classrooms are characterised by pre-class, in-class and post-class activities where students play an active role in their own learning and teachers act as facilitators;

- $\quad$ Pre-class activities typically focus on information transmission i.e., traditionally presented lectures;

- In-class activities typically focus on application and advanced learning activities, traditionally considered homework;

- Post-class activities reinforce pre-class and in-class learning activities;

- In-class activities employ principles of collaborative and active learning that are student centred and include problem solving;

- $\quad$ Flipped classrooms recommend and include the use of technology (video and LMSs) to support activities and goals such as delivering content, self-assessment, and continuous communication with fellow learners and teachers;

- $\quad$ Flipped classrooms include continuous assessment and evaluation. Self-assessment and self-evaluation support learner-centrism and provide an indication of learner progress for context and motivation.

In the following sections the SLR topics are analysed further.

\section{Flipped classroom activities}

Flipped classrooms consist of three distinct activity types namely pre-class, in-class and postclass activities. Several resources used a learning taxonomy to illustrate the difference in intent between these activities (Bagley 2020; Bicen and Beheshti 2019; Selby 2015) as we illustrate in Figure 4 by mapping the learning levels of Bloom's taxonomy (Anderson and Krathwohl 2001; Krathwohl 2002) to flipped classroom activities:

- Pre-class activities are basic learning activities that learners need to complete before class and entail knowledge accumulation and transfer, or the remember and understand according to Bloom. 
- In-class activities are advanced learning activities that support understanding, but focus mainly on applying, analysing and evaluation of learning according to Bloom.

- Post-class activities reinforce the basic and advanced learning activities and apply, analyse, evaluate and to a limited extent even create new constructs or knowledge where applicable.

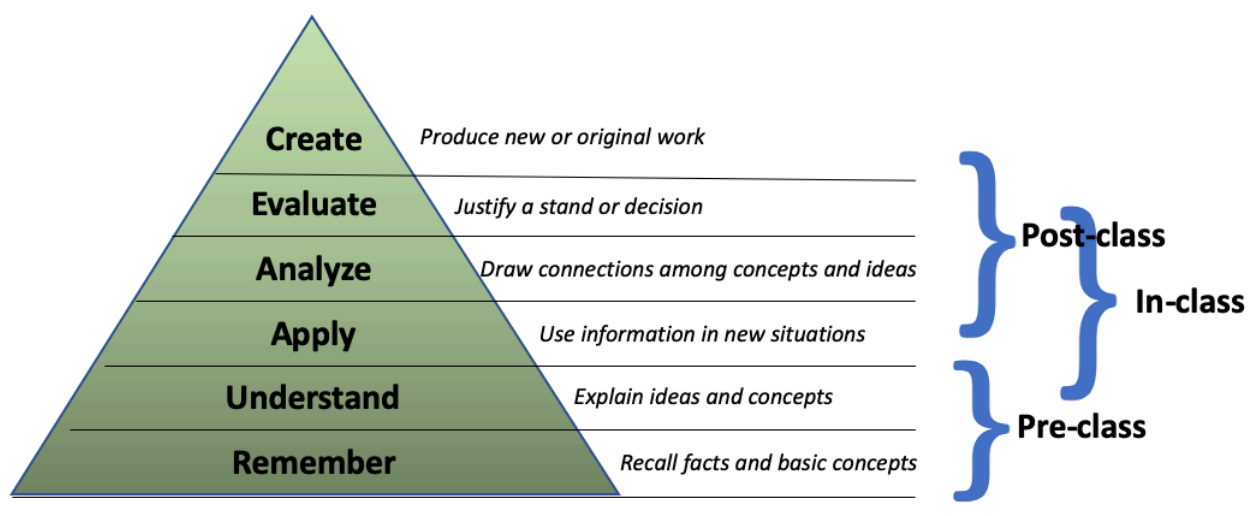

Figure 3: Mapping of flipped classroom activities to Bloom's taxonomy

A challenge identified in our dataset is that learners often do not understand how the flipped classroom activities support each other, and the importance of pre-class activities (Blair, Maharaj, and Primus 2016; Heijstra and Sigurðardóttir 2018). Learners expect what has always been the norm, i.e., they passively attend a class where the main focus is on the transfer of knowledge and explaining concepts and ideas by an instructor. In-class activities require active participation by students in collaborative learning environments, and preparation for in-class activities form part of module design. Preparation does not only facilitate knowledge acquisition, but include exposure to in-class discussion questions, how to communicate and visualize what was learned, as well as mechanisms that support reflection on a student's own experience i.e., what was difficult and why.

\section{Flipped classroom roles}

A prominent distinguishing characteristic of flipped classrooms is the change in roles of learners and instructors. Traditionally learners were passive and all the class activities were instructor-based, and only homework post class would demand that learners engage with content. In the flipped classroom our literature emphasized the need for active learners that engage in pre-class content (hence the recommended use of video's), participate in-class in 
advanced learning activities (apply, analyse and evaluate) and consolidate after class doing homework and revision. A flipped classroom is described as being learner-centred where learners need to play a very active role in their own learning rather than the traditional teachercentred approach in which students are treated as empty vessels that passively absorb information (Akçayır and Akçayır 2018; Fraga and Harmon 2014). The in-class activities need to be carefully designed by instructors to be active, challenging and collaborative so that the necessary learning can take place within a supporting social context. During the in-class activities, secondary skills such as teamwork, communication and application to a specific domain or new setting should be included.

Instructors are mainly facilitators of the learning process and are not responsible anymore for what is dubbed information-transmission. Facilitation in the flipped classroom environment include providing context and continuously supporting the learning process when necessary, not just during class. Communication should include peer-communication and social networking.

The change of roles is identified as core to several challenges in flipped classroom design. Learners often resist the amount of work and associated responsibility, and it is difficult to motivate them to move from being passive until post-class to being active throughout all flipped classroom activities. Many resources therefore document the necessity of, as well as mechanisms to support student engagement (AlJarrah, Thomas, and Shehab 2018; PalazónHerrera 2018). In the end, self-efficacy and psychological ownership of one's own learning and progress remain the prerogative of the learner, and this is emphasized in flipped classrooms. Mechanisms for self-evaluation to understand whether they are mastering content as expected need to be included in the module design (Abeysekera and Dawson 2015; Sergis, Sampson, and Pelliccione 2018; Zainuddin and Perera 2017).

The changing role of the instructor is also recognised as a challenge, especially in higher education where the typical professor is a researcher, scholar and teacher, and not necessarily a skilled facilitator. Being a good facilitator require a special skill-set not emphasized by current job-descriptions in higher education, and one specific case study in our dataset describes a "lethal mutation" of the flipped classroom model where the instructor delegated in-class activities to tutors (Bagley 2020).

\section{Flipped classroom technology support}

Our SLR literature recognises that for an effective flipped classroom, especially in higher education environments, technology is a crucial implementation, infrastructure and delivery component. Technology is the means that support flipped classroom goals and activities, as 
well as the secondary requirements such as role changes, continuous communication and active learning. Two specific technologies are emphasised repeatedly in our SLR dataset, namely videos supporting pre-class activities, and Learning Management Systems (LMSs). LMSs are used for providing the module structure in an environment where the teacher is not always available and is not central to information delivery (Liu 2019; Lopes, Gouveia, and Reis 2019). LMSs are also necessary to facilitate self-paced and always-available delivery of content, continuous communication with peers and facilitators, and self-evaluation with regards to progress towards the learning outcomes.

A plethora of resources discuss the effectiveness, design, opportunities and challenges of video content that support learning, and within the flipped classroom context, these videos support pre-class activities specifically (Schneider and Blikstein 2016; Robinson et al. 2020; Tuna et al. 2017; Kay et al. 2019). Videos often consist of recorded lectures and voice-over slides, however, it is emphasized that boring, ineffective pre-class material is one of the primary challenges, especially because learners need to be engaged and motivated for effective preparation (Long, Logan, and Waugh 2016; Turan and Cetintas 2019; Robinson et al. 2020).

Challenges mentioned repeatedly is cost, time, technology, resources and skills necessary for the implementation of flipped classrooms, both with regards to the infrastructure and LMSs, as well as the creation of relevant (video) content (Triantafyllou and Timcenko 2015; Shnai 2017; Pellas 2018). An identified implementation challenge is resistance of faculty to the workload necessary for the development of pre-class preparation content. A sub-set of literature discuss MOOCs in flipped classrooms to assist with pre-class content, especially in resource constrained countries where the facilities to develop own content are limited (Song, Song, and Wei 2015; Hung, Sun, and Liu 2019). When using MOOC's or other available video content to support pre-class activities, the challenge is to ensure alignment with the overall curricula, module objectives and outcomes.

\section{Theory relevant for flipped classrooms}

In this last section we provide a summary of theories identified in the SLR dataset since the theories would inform the design considerations.

Constructivist learning theory ${ }^{2}$ was identified as a theoretical foundation for the flipped classroom model, specifically supporting the learner-centric basis (Hodges and Weber 2015; Olusegun 2015). In constructivism it is accepted that the learner has prior knowledge and experiences, and learning happens when knowledge is created out through past and present experiences (Hein 1991; Vanderstraeten 2002; Richardson 2003). Active learning theory is closely associated with constructivist learning theory (Bonwell and Eison 1991). Active 
learning theory emphasizes active participation and involvement of students in the learning process and this theory is applicable given the fundamental learner-centric departure point of the flipped classroom approach (Fraga and Harmon 2014; Giannakos, Krogstie, and Aalberg 2016; Keenge and Onchwari 2016; Hwang, Yin, and Chu 2019; Borda et al. 2020). Studentcentred learning embodies a set of theories that include active learning, peer-assisted learning, and collaborative learning (Bishop et al. 2013; Akçayır and Akçayır 2018). Peer-assisted learning is often used as an umbrella term for learning supported by peers (Boud, Cohen, and Sampson 1999) and collaborative learning is characterised by (often designed) situations in which two or more people collaborate to learn together. Learners borrow from each other's insight, resources and skills (Dillenbourg et al. 1995).

Self-determination theory (SDT), as well as cognitive load theory were identified as possible lenses for studying flipped classrooms (Abeysekera and Dawson 2015). SDT is a macro theory of human motivation that postulates that humans motivate themselves when needs for competence, connection, and autonomy are fulfilled (Deci and Ryan 2014; Cherry 2019), and cognitive load theory postulates that short-term working memory is limited and that learning experiences should be designed to reduce working memory load (Sweller, Ayres, and Kalyuga 2011). Motivation is also supported by the theory of gamified learning that is applicable to mechanisms that support student engagement and motivation (Kapp 2012; Özer, Kanbul, and Ozdamli 2018). Gamification has "become a popular technique used across a variety of contexts to motivate people to engage in particular targeted behaviours" and theory that apply these principles to learning resulted in theories of gamified learning (Landers 2014).

\section{DISTINGUISHING CHARACTERISTICS OF FLIPPED CLASSROOMS}

In Table 1 we consolidate the results of the SLR. The borders between the different teaching approaches are not always clear cut, and most modern teaching approaches can be classified somewhere between the traditional and flipped classroom approaches, however, for the purpose of designing an online flipped classroom, we focus on what distinguishes, and we analyse according to the identified activities. Within activities we discuss roles and technology support.

Table 1: Distinguishing Characteristics of Flipped Classrooms

\begin{tabular}{|lll|}
\hline \multicolumn{1}{|c|}{ Traditional Classrooms } & \multicolumn{1}{c|}{ Flipped Classroom } \\
\hline Fundamental & Teacher centred. & Learner or student centred. \\
General & Classical curriculum construction and & Classical curriculum construction and module \\
Design & $\begin{array}{l}\text { module design is centred around } \\
\text { content delivery and topics to be taught } \\
\text { during class. The module structure is } \\
\text { communicated through class schedules } \\
\text { and study guides. }\end{array}$ & $\begin{array}{l}\text { topics to be taught during class. The module } \\
\text { structure is communicated through class } \\
\text { schedules and study guides. }\end{array}$ \\
& & \\
& & \\
& &
\end{tabular}




\begin{tabular}{|c|c|c|}
\hline & Traditional Classrooms & Flipped Classroom \\
\hline Technology & $\begin{array}{l}\text { Optional and usually included to assist } \\
\text { with making knowledge transfer } \\
\text { interesting. }\end{array}$ & $\begin{array}{l}\text { Indispensable. LMSs communicate module } \\
\text { structure, expectations, goals, progress and } \\
\text { mastery, as well as facilitate assessment and any- } \\
\text { time access to content. }\end{array}$ \\
\hline \multirow[t]{2}{*}{ Roles } & Instructor: Content custodian & Instructor: Learning facilitator. \\
\hline & Learner: Passive information receiver. & $\begin{array}{l}\text { Learner: Active, engaged, need to take ownership } \\
\text { of own learning }\end{array}$ \\
\hline \multirow[t]{2}{*}{$\begin{array}{l}\text { Pre-Class } \\
\text { Activities }\end{array}$} & \multirow{2}{*}{$\begin{array}{l}\text { Preparation for class either omitted or } \\
\text { may include a non-enforced } \\
\text { expectation. }\end{array}$} & $\begin{array}{l}\text { Preparation for class is crucial and in-class } \\
\text { activities fail if student do not prepare. }\end{array}$ \\
\hline & & $\begin{array}{l}\text { Most of a flipped classroom's content delivery } \\
\text { happens pre-class through carefully designed } \\
\text { delivery mechanisms (including video). }\end{array}$ \\
\hline Technology: & $\begin{array}{l}\text { Modern approaches include LMSs to } \\
\text { provide 'passive' learning materials } \\
\text { (e.g., books and slides). }\end{array}$ & $\begin{array}{l}\text { Prerequisite for delivery of preparation materials } \\
\text { and normative assessment. }\end{array}$ \\
\hline \multirow[t]{2}{*}{ Roles: } & Instructor: Content custodian & Instructor: Content provider e.g., creating videos. \\
\hline & $\begin{array}{l}\text { Learner: Passive, in contrast with } \\
\text { flipped classrooms preparation is } \\
\text { preferable but not crucial }\end{array}$ & $\begin{array}{l}\text { Learner: Preparation is crucial and often a } \\
\text { necessary prerequisite to class attendance }\end{array}$ \\
\hline $\begin{array}{l}\text { In-Class } \\
\text { Activities }\end{array}$ & $\begin{array}{l}\text { Primarily based on information } \\
\text { transmission and delivery activities, as } \\
\text { well as explanation, seldom advanced } \\
\text { learning such as application and } \\
\text { analysis. }\end{array}$ & $\begin{array}{l}\text { Primarily based on advanced learning activities, } \\
\text { application and analysis. These activities depend } \\
\text { on class preparation and often fail without such } \\
\text { preparation. Incorporates principles of active } \\
\text { learning, discussion and collaborative teamwork. }\end{array}$ \\
\hline Technology: & $\begin{array}{l}\text { Used in-class to support lecture and } \\
\text { content delivery. }\end{array}$ & $\begin{array}{l}\text { Facilitates discussion and advanced learning } \\
\text { activities. }\end{array}$ \\
\hline \multirow[t]{2}{*}{ Roles: } & \multirow[t]{2}{*}{$\begin{array}{l}\text { Instructor: Information transmission. } \\
\text { Learner: Passive, Information receiver. }\end{array}$} & $\begin{array}{l}\text { Instructor: Facilitator of carefully designed and } \\
\text { collaborative in-class advanced learning activities }\end{array}$ \\
\hline & & $\begin{array}{l}\text { Learner: Learners not only prepare by mastering } \\
\text { pre-class content but also prepare for in-class } \\
\text { activities by identifying problems, discussion } \\
\text { topics and organizing teamwork. }\end{array}$ \\
\hline $\begin{array}{l}\text { Post-Class } \\
\text { Activities }\end{array}$ & $\begin{array}{l}\text { Homework post-class are used for } \\
\text { advanced learning activities e.g., } \\
\text { projects that apply knowledge, group } \\
\text { work etc. Post-class activities for the } \\
\text { first time really expect engagement } \\
\text { from students. }\end{array}$ & $\begin{array}{l}\text { Post-class activities are designed for } \\
\text { reinforcement of learning and revision. }\end{array}$ \\
\hline Technology: & Inclusion optional. & $\begin{array}{l}\text { Allows further engagement and learning support, } \\
\text { as well as normative and summative assessment. }\end{array}$ \\
\hline \multirow[t]{2}{*}{ Roles: } & $\begin{array}{l}\text { Instructor: Evaluation and assessment } \\
\text { of content learning }\end{array}$ & $\begin{array}{l}\text { Instructor: Facilitate and reinforce learning and } \\
\text { communication. }\end{array}$ \\
\hline & $\begin{array}{l}\text { Learner: Engage actively in homework } \\
\text { activities. }\end{array}$ & $\begin{array}{l}\text { Learner: Complete post-class evaluations and } \\
\text { assessment, primarily for revision, reflection and } \\
\text { reinforcement of learning }\end{array}$ \\
\hline Assessment & $\begin{array}{l}\text { Assessment mostly summative and } \\
\text { post-class and its purpose is primarily } \\
\text { to evaluate content mastery. }\end{array}$ & $\begin{array}{l}\text { Assessment is often normative and has as primary } \\
\text { purpose to support learning e.g., learners are able } \\
\text { to evaluate their own progress and mastery } \\
\text { throughout the learning experience. Assessments } \\
\text { are designed to support learning. }\end{array}$ \\
\hline \multirow[t]{2}{*}{ Roles: } & $\begin{array}{l}\text { Instructor: Evaluation and assessment } \\
\text { of content learning }\end{array}$ & $\begin{array}{l}\text { Instructor: Facilitate assessment so that learners } \\
\text { can engage and own learning progress. }\end{array}$ \\
\hline & $\begin{array}{l}\text { Learner: Learners engage with mostly } \\
\text { summative assessment in order to } \\
\text { evaluate their mastering of content. }\end{array}$ & $\begin{array}{l}\text { Learner: Complete assessment, both normative } \\
\text { and summative to evaluate own learning progress } \\
\text { and mastery. }\end{array}$ \\
\hline
\end{tabular}

In the next section the distinguishing characteristics are used to develop design considerations for converting a traditional module to an online flipped classroom. 


\section{DESIGN CONSIDERATIONS FOR FLIPPED CLASSROOMS}

The first step to extract design considerations is to consider the identified theory from the SLR as presented in Section 4.5. The design considerations are indicated in italics.

Table 2: Theory-based Design Considerations for Flipped Classrooms

\begin{tabular}{|c|c|}
\hline Theory & Theory-based Design Considerations \\
\hline \multirow[t]{2}{*}{$\begin{array}{l}\text { Constructivist theory; } \\
\text { active learning theory }\end{array}$} & $\begin{array}{l}\text { Constructivist theory supports the learner-centric departure point and emphasizes that } \\
\text { learning happens when knowledge is created out of experiences. Active learning } \\
\text { theory emphasizes the need for active participation and involvement of learners in the } \\
\text { learning process. }\end{array}$ \\
\hline & $\begin{array}{l}\text { Design holistically for learner-centric and active learning experience: Flipped } \\
\text { classrooms need to be designed holistically, all activities should support each other as } \\
\text { part of the design. Active participation of leaners should be core to activity design that } \\
\text { support learning from individual experience. }\end{array}$ \\
\hline \multirow[t]{2}{*}{$\begin{array}{l}\text { Peer-assisted and } \\
\text { collaborative learning } \\
\text { theory }\end{array}$} & $\begin{array}{l}\text { Peer-assisted and collaborative learning focus on effective learning characterised by } \\
\text { (often designed) situations in which two or more people collaborate to learn together } \\
\text { and learners borrow from each other's insight, resources and skills. }\end{array}$ \\
\hline & $\begin{array}{l}\text { Design to include collaborative learning: This is of particular concern in flipped } \\
\text { classroom in-class activities where collaboration and teamwork is emphasized and } \\
\text { post-class collaborative environments may include discussion forums and social } \\
\text { media platforms. }\end{array}$ \\
\hline \multirow[t]{2}{*}{$\begin{array}{l}\text { Self-determination } \\
\text { theory }\end{array}$} & $\begin{array}{l}\text { Self-determination theory is a macro theory of human motivation that postulates that } \\
\text { humans motivate themselves when needs for competence, connection, and autonomy } \\
\text { are fulfilled, and this is regarded as essential to ensure that learners are engaged in } \\
\text { the flipped classroom environment. }\end{array}$ \\
\hline & $\begin{array}{l}\text { Design to include learner self-motivations through competence, connection, and } \\
\text { autonomy: Flipped classroom design should indicate the path to subject mastery, } \\
\text { include connection with peers and facilitators and autonomy through course design } \\
\text { and delivery. }\end{array}$ \\
\hline \multirow[t]{2}{*}{ Cognitive load theory } & $\begin{array}{l}\text { Cognitive load theory emphasizes the learning approaches that take into account the } \\
\text { limited nature of short-term working memory and stresses that learning experiences } \\
\text { should be designed to reduce working memory load }\end{array}$ \\
\hline & $\begin{array}{l}\text { Design activities taking short-term cognitive load into account: Considering cognitive } \\
\text { load theory would entail that a flipped classroom module is designed using mini- } \\
\text { curricula, and that, for instance, any content be packaged as short and succinct self- } \\
\text { contained modules }\end{array}$ \\
\hline \multirow[t]{2}{*}{$\begin{array}{l}\text { Theory of gamified } \\
\text { learning. }\end{array}$} & $\begin{array}{l}\text { Theory of gamified learning uses gaming constructs across a variety of contexts to } \\
\text { motivate people to engage in particular targeted behaviours. }\end{array}$ \\
\hline & $\begin{array}{l}\text { Design flipped classroom modules and activities to include mastery and progress } \\
\text { rewards: Mastery and learning should be rewarded, reward mechanisms such as } \\
\text { points and badges could be awarded as a learner progresses through a module. } \\
\text { Competition could be included in module design. }\end{array}$ \\
\hline
\end{tabular}

\section{Design considerations for online flipped classrooms}

When combining the theory perspectives depicted and described in Table 2 with the results from the SLR with regards to flipped classroom definitions, characteristics and core concepts, we identified the design considerations for online flipped classrooms as described in Table 3 below. The theory design considerations of the previous section were included and we number each of design consideration for reference purposes. 
Table 3: Design Considerations for Online Flipped Classrooms

\section{Design Considerations}

DC1: Design flipped classroom module holistically taking all its differentiating characteristics into account namely engaged, active and collaborative learner-centred learning. Pre-class, in-class and post-class activities should support each other as part of the complete flipped classroom design.

$D C 2$ : Design the flipped classroom as small succinct mini-curricula modules (short-term cognitive load) to allow for students to understand what is necessary for preparation, participation and homework. Include relevant assessment mechanisms. When a course is designed, the overall curriculum as well as the mini-curricula centred around classes could to be designed and mapped to learning outcomes, and these learning outcomes should typically be based on a learning taxonomy such as Bloom.

$D C 3$ : Design pre-class activities to typically conform to the remember and understand learning levels if we use Bloom's taxonomy.

Material for pre-class activities should:

- $\quad$ be well structured with normative assessment and progression goals;

- $\quad$ be structured in such a way that material is presented in short videos; an content groups that conforms to recommendations of cognitive load theory;

- $\quad$ support multi-modal, asynchronous and restricted bandwidth availability, e.g. through videos, slides and documents.

DC4: Design in-class activities to typically conform to the higher levels of learning, e.g. the apply, analyse and evaluate levels of Bloom's taxonomy, and the structure, intent, expectations and outcomes communicated.

$D C 5$ : Design post-class activities to reinforce, revise and consolidate learning. Post-class activities could form part of summative assessment.

DC6: Design for active and engaged learner experience. Learners should change from passive observers to active and engaged participants.

$D C 7$ : Design for instructor facilitation: The facilitating role of instructors as well as mechanisms for facilitation of the individual learner should be designed into a flipped classroom structure.

DC8: Design flipped classroom modules and activities to include mastery and progress rewards: Assessment should be designed to support individual experience, engagement and progress, as well as mastery. Normative assessment mechanisms should be used to support individual learner progress and achievements. Summative assessment should be communicated and should evaluate not only content mastery as is done on traditional teaching, but fundamental principles of flipped classrooms such as learner engagement and activity completion.

DC9: Design to include gamification and self-determination theory principles: Learners could be rewarded for progress, competition on various levels could be included in the module design, also for collaborative (e.g. team) or peer-participation.

DC10: Design flipped classrooms so that technology to provide structure: LMSs should facilitate the structured delivery of subject matter through the relevant activities.

DC11: Design flipped classrooms so that technology assist with learner progress through mini-curricula: LMS functionality should be included to assist with learner progress, as well as own-time and asynchronous learning according to individual needs. Pre-class, in-class and post-class activities should support each other as part of the whole flipped classroom design. LMSs should facilitate the structured delivery of subject matter through the relevant activities.

DC12: Design flipped classrooms for collaboration and peer participation: Overall, collaborative technology such as discussion forums and social media platforms could be incorporated into flipped classroom design, in activities and as part of support structures.

DC13: Design communication structures: Communicate fundamental principles of flipped classrooms as well as objectives, expectations, roles and goals: Instructors and learners should understand what a flipped classroom is, how a module based on the flipped classroom is constructed. Learners should understand their role as well as those of instructors as mainly facilitators. What this facilitation entails should be clear for all participants.

In the next section we demonstrate the application of the general identified design considerations within a specific context. The context imposes some additional design considerations, which is presented first. 


\section{Context: COVID-19, Higher Education and a Developing Country}

With the outbreak of the COVID-19 pandemic, South-Africa joined the world in implementing lockdown measures with severe restrictions on travel and movement, (DoH 2020). All higher education institutions moved to rescue the academic year through online teaching (Shoba 2020), and students also had to return home and are not allowed to travel or to access campuses. Our institution specifically has been promoting hybrid learning (learning on-site as well as online) including the flipped classroom defined as an approach "... which requires students to read, research, view videos and do online quizzes prior to class so that classroom time can be used more effectively" (Gower 2019). With the move to online teaching only, several observations about the inequality in a developing country such as South Africa were pushed into the limelight as is evident in the address of a vice-chancellor on World Telecommunication and Information Society Day (17 May 2020) where he observed that the digital divide or inequal access to digital resources affects a large number of students (Kupe 2020). Because students had to return home, often to remote and rural areas of South Africa, they are often severely challenged to study online and the institution grappled with assisting disadvantaged students with computer equipment, as well as negotiating reduced data rates for internet access through national Mobile Network Providers (MNPs) in order to allow them to continue their studies. Several MNPs assisted by making data through the $3 \mathrm{G}$ network available for free for students to connect to the institutional Learning Management System (LMS), however, the 3G network speed is mostly low in general. The inequal access to resources enforced additional requirements to the design of online teaching such as that online video classes that required continues high-bandwidth access that are not accessible to disadvantaged students from rural communities.

Most students as typical Gen Z-ers embraced technology and technology supported learning environments and in our case, were generally comfortable with moving to online teaching, however they demanded services that are available at any time and with low barriers to access (Savage 2006; Kozinsky 2017). Gen Z-ers (or Generation Z) are born after 1990 and their births coincides with the birth of the World Wide Web (WWW). Gen-Z is comfortable with mobile and internet technology, and subsequently expected that some form of online teaching will be available (Savage 2006; Kozinsky 2017). They are comfortable with the availability of online learning material in general, however, not necessarily with the changing role expected from learners in the fundamental flipped classroom approach (Gilboy et al. 2015; Zainuddin and Perera 2017; Steen-Utheim and Foldnes 2018).

A further consideration in course redesign is that the scope should not exceed the expected nominal hours coupled with the accreditation, and a certain number of hours need to be contact 
sessions (even if the contact sessions are online). Activities should therefore be designed taking existing scope into account. The context specific design considerations that we identified are presented in Table 4 and most provide additional requirements given general design considerations in Table 3.

Table 4: Context Specific Design Considerations for Online Flipped Classrooms

\begin{tabular}{|c|}
\hline \\
\hline $\begin{array}{l}\text { DC14: Design to use technology to support context requirements: Students are sen } \\
\text { typically Gen-Z students that interact daily as well as prefer technology in the current lo } \\
\text { the class with flexibility and multi-model delivery mechanisms to mediate inequal acce }\end{array}$ \\
\hline $\begin{array}{l}\text { DC15: Design for communication given specific context requirements: Provide additional assistance for } \\
\text { compliance, especially for disadvantaged students in challenging home environments. They should know exactly } \\
\text { what is expected from them, when it is expected and how to comply, especially if they are not physically on } \\
\text { campus with access to a supporting environment and peer-learners. }\end{array}$ \\
\hline $\begin{array}{l}\text { DC16: Design for flexible context access (both means of access and time of access): Allow flexibility with regards } \\
\text { to content access so that students that do not have access to high-bandwidth resources are not excluded. This } \\
\text { would include that students do not need to access specific content at a specific time but they should be able to } \\
\text { schedule downloads during night time for instance. Class sessions should also not penalize students that cannot } \\
\text { attend during a specific time, but this does not replace classes. There should be more than one way in which } \\
\text { participation is acknowledged, and this approach require clear communication. }\end{array}$ \\
\hline $\begin{array}{l}\text { DC17: Design for context specific participation and collaboration: Include mechanisms that ensure that remote } \\
\text { and isolated students are incorporated into learning communities. The isolation situation includes a lack of } \\
\text { relevant social interaction, and therefore the requirement that a flipped classroom platform should facilitate } \\
\text { learning communities and peer-learning through available social-media platforms (e.g., WhatsApp) and LMSs } \\
\text { mechanisms such as dedicated discussion forums where students can interact with peer-learners and } \\
\text { instructors. }\end{array}$ \\
\hline \\
\hline $\begin{array}{l}\text { DC19: Design for flexible and multi-modal access pre-class: The main design consideration is therefore flexibility } \\
\text { and that the flipped classroom module is designed in such a way that learners are not disadvantaged } \\
\text { independent of bandwidth and resource access. A solution includes multi-modal access, which allows learners } \\
\text { to access and download content whenever possible. Learners could schedule the downloading of videos during } \\
\text { night-time when bandwidth from MNPs is more affordable and available. }\end{array}$ \\
\hline $\begin{array}{l}\text { DC20: Design for multi-modal class participation: Online-lecture in-class sessions should be available for } \\
\text { learners with sufficient bandwidth access, but these sessions should preferably be recorded and made available } \\
\text { for those learners without inadequate access. Pre-class content should be available in a format that support } \\
\text { restricted resources, and Q\&A sessions could be scheduled for recorded in-class sessions as well as be handled } \\
\text { in moderated discussion forums. }\end{array}$ \\
\hline $\begin{array}{l}\text { DC21: Design for collaboration and teamwork post-class: Post-class activities need reinforcement and } \\
\text { collaborative environments that could be provided by technology. }\end{array}$ \\
\hline \\
\hline
\end{tabular}

\section{CONVERT AN INFORMATION SYSTEMS MODULE TO AN INCLUSIVE ONLINE FLIPPED CLASSROOM}

Detailed evaluation of the design considerations is beyond the scope of this article, however, we converted a short module on IS theory in the Information Systems (IS) department and we shortly report on our experience. The institution uses Blackboard LMS (Blackboard 2020). In Table 5 we indicate the applicable design considerations by referring to their numbers assigned 
in Tables 3 and 4.

Table 5: Demonstration of Design Considerations for Online Flipped Classrooms

\section{Flipped Classroom IS Theories Module}

The introductory IS Theories curriculum were analysed and designed to consist of 6 sessions or min-curricula each with required reading material, a short video (short max 8-10min content videos) based on the slides that were traditionally presented in class, as well as a short preparation assessment. The learning outcomes were mapped to the mini-curricula. Each mini-curriculum also included teaser questions to be discussed in the online class discussion session. Design considerations DC1, DC2, DC11, DC22.

- The home page of the IS Theories contains the overall module summary and objectives, as well as an explanation the flipped classroom approach, how the module is structured as well as expectations and roles. Design considerations DC2, DC11'DC13.

- A description of the types of activities and how they support each other is provided. In addition, the preparation activities are emphasized, as well as the how the preparation will be evaluated and assessed. Design considerations DC1, DC2, DC3, DC11, DC13.

- The roles of learners as learning owners, and instructors as facilitators, as well as the associated expectations, were emphasized often. Design considerations DC11, DC13.

Pre-class activities introduce content in a structured manner with short videos based on traditional slides, reading material and assessment. The content was made available in different formats to also ensure inclusion. Design considerations $D C 1, D C 3, D C 11$

In-class activities were designed given the mini-curriculum perspective and facilitate applied and advanced learning and discussion in the class. Design considerations DC1, DC3, DC7.

- The in-class session expected students to be prepared, no knowledge transfer activities were included. The instructor was online with a video switched on, whilst students were sked to mute microphones and switch off video cameras to reduce bandwidth use. The LMS was used to facilitate the discussion, and students could participate through comments or by raising a hand and switching on their videos. The session was recorded and the recording was made available in lower resolution for students that cannot attend class. Design considerations DC4, DC6, DC7, DC11, DC16-20

- In-class the lecturer/instructor focused on facilitation of the activities and discussions, and students could post questions, participate and comment. Design considerations DC6, DC7, DC13.

- In-class activities used case-based scenarios for discussion and application of topic content. Several examples were used in-class to illustrate concepts and learners were expected to contribute to discussions. Design considerations DC4, DC6, DC11, DC12, DC13.

Post-class activities reinforced learning with an application assignment that specifically focused on aspects of the advanced in-class activities and not on preparation (part of the module summative assessment). In our module the post-class homework was an application assignment. Design considerations $D C 1, D C 2, D C 5, D C 21$.

The LMS we used is the institutional LMS namely Blackboard. For the department there are some templates that ensure consistency, and we adapted the template to communicate and provide the structured delivery of the module content. Design considerations DC10, DC11, DC14, DC17.

- It is possible to view learner activity and progress, as well as scores through the LMS activity log. The time spent on each activity can be individually monitored by facilitators and interventions could be designed if there are concerns. Design considerations DC7.

- The calendar functionality was also used so that students can see in the calendar what they are supposed to do when, e.g., when to prepare, what to prepare, when to participate in class and what to do post-class when. Design considerations DC2, DC6, DC11, DC15.

- $\quad$ LMS mechanisms such as progress badges, adaptive release and calendars could assist with communication, student support and student progress. Design considerations DC6, DC9, DC11.

- All content is made available in the LMS and are developed for multi-modal access e.g., being downloadable so that low-bandwidth downloads can be scheduled by learners with limited access. Design considerations DC10, DC11, DC14, DC16

- To support inclusion, in-class activities use the online classroom technology of the LMS. The discussion and chat functionality are used to get feedback, comments and questions. All the aspects of the session were recorded and made available in low-bandwidth downloadable format. Most of the session was voice except for instructor video. All students do not have the bandwidth for video streaming, and all sessions will be made available for asynchronous access and scheduled download later. Design considerations DC7, DC10, DC14, DC16-20

Assessment: Normative assessment and summative is per individual and primarily based on student participation in the activities, assessments and final assignment, which is logged by the LMS. Design considerations DC8, DC14. 
- $\quad$ For modules that are part of the official degree offering of the institution students have to obtain semester marks as well as write a moderated exam. The semester marks are calculated by taking completion of preparation activities into account, in-class discussion and group assignments, as well as their post-class assignments or projects Design Considerations DC8, DC10.

- A short preparation assessment (containing random multiple choice questions) per topic is included and students can complete the assessment until they achieved an $80 \%$ score. Only completion of the assessment is taken into consideration for final marks. Design considerations DC6.

- $\quad$ The LMS supports discussion forums as part of the module setup, and these discussion forums were included in the module design. The instructor facilitated discussion and some activities expected students to post on the discussion forum. Design considerations DC7, DC10, DC11, DC12-14.

Class representatives: Even though not used for our module, class representatives could be tasked to organise student communities and ensure that all students are contacted and belong to a social media platform. If students do not participate in module activities, they could be contacted and interventions will be made available depending on the challenges they experience Design considerations DC7, DC12, DC15, DC17-21.

\section{EXPERIENCE REPORT}

When we applied the developed online flipped classroom design considerations to convert a short IS theories module, the detail considerations of Tables 3 and 4 were useful as it allowed us to focus on specific aspects of the module, however, we found that the design considerations need to be applied taking the fundamental distinguishing characteristics of flipped classrooms into account. We had to guard against legacy-creep and falling back to existing patterns. A true flipped classroom is not just a classical teaching approach where students are given some preparation work to do before class, and where technology such as a LMS is used to assist with the dissemination of module materials.

The generation of the preparation content was time consuming, but an advantage is that it is available for future teaching and the mini-curriculum approach makes it possible to only revise sections or units should it be necessary in future. We also found it difficult to include the gamification mechanisms into the course, and in the end this part did not work well. Future research will investigate gamification mechanisms and how to effectively integrate it into the online flipped classroom environment.

We made expectations with regards to preparation, class and homework clear, and emphasized that classroom sessions would be for discussion only. We started the classroom session with a request for general feedback on the flipped classroom approach. Learners indicated that the structure and expectations of the flipped classroom approach that were clearly communicated assisted them to plan and complete activities because they knew what to do and by when. More than 65 per cent of students commented that the videos were very useful, and they found the fact that they could revisit discussions in the video one of the most valuable aspects compared to traditional classrooms where complicated concepts were often only discussed once in a short space of time with no chance of reflection and revisit. We could also confirm this behaviour by viewing access logs of the material on the LMS. 
Attendance of the class sessions was good, of the enrolled 35 students, more than 30 usually attended but some students dropped continuously due to connectivity issues. They however managed to join for short periods and indicated that the recorded class session would be valuable and they would contact fellow students and instructors through the available communication channels should they have further questions. Not unexpectedly there were few students that did not sufficiently prepare for class, but other students in the group commented on their questions and pointed them to the preparation materials. Prepared students wanted to use the discussion time effectively. This group correction behaviour was an interesting and unexpected observation and support for this peer-behaviour could be supported by revised design considerations.

The post-class assignment is similar to what was used in the traditional module, however, students indicated that they feel better prepared due to the online class session and the opportunities they had to discuss their individual problems that were identified during preparation. The quality of submissions was better and students generally performed better. Further research could include a comparative study on student performance.

We only evaluated the online flipped classroom design considerations for a short module and further research would include evaluation and refinement given the conversion of semester modules in data warehousing and data mining that need to move online.

\section{CONCLUSION}

In this article we report on a study to convert to online flipped classrooms that was necessitated by the Covid-19 pandemic in a higher education institution that had to convert to online teaching. The study consisted of two parts with two contributions. A Systematic Literature Review (SLR) was used as method in order to identify the distinguishing characteristics of the to-be flipped classroom approach with the classical traditional as-is teaching approach. From the SLR we found that the primary distinguishing characteristics of flipped classrooms include the fundamental theoretical learner-centric departure point that depend on active and engaged learners, three distinct types of learning activities, and a change in the primary role of the instructor from a teacher to a facilitator. Foundational to flipped classrooms is constructivism, which means that the online environment should actively and uniquely support individuals to learn through experience provided by the learning environment, engage in pre-class preparation through interesting and well-developed content, participate in in-class collaborative discussion and reflect post-class to reinforce learning.

The distinguishing characteristics of the flipped classroom approach were subsequently used to develop design considerations for converting to online flipped classrooms. The design 
considerations integrated principles from relevant theory and specific context circumstances given the Covid-19 pandemic in a developing country with a digital divide and unequal access to resources. The design considerations were demonstrated by redesigning a short module in IS Theories to be an inclusive online flipped classroom module. After understanding what a flipped classroom really is and how the as-is module differs from the to-be online flipped classroom, we found that the design considerations were practical and ensured that the detail design is consistent. We found that the design considerations by themselves are not effective without understanding what the to-be online flipped classroom scenario fundamentally entails and how it differs from the as-is traditional teaching scenario.

The nature of higher education will in all probability never change back to what it was before Covid-19, and our contributions could assist instructors to position for the new normal of alternative online teaching approaches. The specific context of this study, namely the Covid19 pandemic necessitating that all higher education teaching is transformed to be online, as well as inclusion considerations online in a digitally-divided developing country that influences online teaching environments distinguish our study from the plethora of existing literature on flipped classrooms.

\section{NOTES}

1. We did not include citations to all 167 publications in this article.

2. We report on SLR results and it is beyond the scope of this discussion to give a detailed overview of the different perspectives of constructivist theory such as reflected in the seminal publications of Dewey (1929), Bruner (1961), Vygotskii (2012) and Piaget (1980).

\section{REFERENCES}

Abeysekera, Lakmal and Phillip Dawson. 2015. "Motivation and Cognitive Load in the Flipped Classroom: Definition, Rationale and a Call for Research." Higher Education Research \& Development 34(1): 1-14. https://doi.org/10.1080/07294360.2014.934336.

Akçayır, Gökçe and Murat Akçayır. 2018. "The Flipped Classroom: A Review of Its Advantages and Challenges." Computers \& Education 126(November): 334-45. https://doi.org/10.1016/ j.compedu.2018.07.021.

AlJarrah, Abeer, Michael K. Thomas, and Mohamed Shehab. 2018. "Investigating Temporal Access in a Flipped Classroom: Procrastination Persists." International Journal of Educational Technology in Higher Education 15(1). https://doi.org/10.1186/s41239-017-0083-9.

Anderson, Lorin W. and David R. Krathwohl. (Ed.). 2001. A Taxonomy for Learning, Teaching, and Assessing: A Revision of Bloom's Taxonomy of Educational Objectives. Complete ed. New York: Longman.

Bagley, Spencer. 2020. "The Flipped Classroom, Lethal Mutations, and the Didactical Contract: A Cautionary Tale." PRIMUS 30(3): 243-60. https://doi.org/10.1080/10511970.2018.1555196.

Bicen, Huseyin and Mobina Beheshti. 2019. "Assessing Perceptions and Evaluating Achievements of ESL Students with the Usage of Infographics in a Flipped Classroom Learning Environment." Interactive Learning Environments October: 1-29. https://doi.org/10.1080/ 
10494820.2019.1666285.

Bishop, Jacob Lowell, Utah State University, Dr Matthew A. Verleger, Embry-Riddle Aeronautical Univ, and Daytona Beach. 2013. "The Flipped Classroom: A Survey of the Research." In Proceedings of the $120^{\text {th }}$ ASEE Annual Conference \& Exposition, 18-35, American Society for Engineering Education.

Blackboard. 2020. “Blackboard Learn.” Blackboard. 2020. https://www.blackboard.com/teachinglearning/learning-management/blackboard-learn.

Blair, Erik, Chris Maharaj, and Simone Primus. 2016. "Performance and Perception in the Flipped Classroom." Education and Information Technologies 21(6): 1465-1482. https://doi.org/10.1007/ s10639-015-9393-5.

Bonwell, C. and J. Eison. 1991. Active Learning: Creating Excitement in the Classroom AEHE-ERIC Higher Education Report No. 1. Washington, D.C.: Jossey-Bass.

Borda, Emily, Emily Schumacher, Daniel Hanley, Edward Geary, Shannon Warren, Cassidy Ipsen, and Lauren Stredicke. 2020. "Initial Implementation of Active Learning Strategies in Large, Lecture STEM Courses: Lessons Learned from a Multi-Institutional, Interdisciplinary STEM Faculty Development Program." International Journal of STEM Education 7(1). https://doi.org/10.1186/s40594-020-0203-2.

Boud, David, Ruth Cohen and Jane Sampson. 1999. "Peer Learning and Assessment." Assessment \& Evaluation in Higher Education 24(4): 413-26. https://doi.org/10.1080/0260293990240405.

Bralić, Antonia and Blaženka Divjak. 2018. "Integrating MOOCs in Traditionally Taught Courses: Achieving Learning Outcomes with Blended Learning." International Journal of Educational Technology in Higher Education 15(1). https://doi.org/10.1186/s41239-017-0085-7.

Bruner, Jerome S. 1961. "The Act of Discovery." Harvard Educational Review 31: 21-32. https://psycnet.apa.org/record/1962-00777-001.

Chan, Siok-Yee, Yat Kuan Lam, and Theam Foo Ng. 2018. "Student's Perception on Initial Experience of Flipped Classroom in Pharmacy Education: Are We Ready?" Innovations in Education and Teaching International November: 1-12. https://doi.org/10.1080/14703297.2018.1541189.

Cherry, Kendra. 2019. "Self-Determination Theory and Motivation." Verywell Mind (blog). 2019. https://www.verywellmind.com/what-is-self-determination-theory-2795387.

Chiang, Tosti Hsu-Cheng. 2017. "Analysis of Learning Behavior in a Flipped Programing Classroom Adopting Problem-Solving Strategies." Interactive Learning Environments 25(2): 189-202. https://doi.org/10.1080/10494820.2016.1276084.

Deci, Edward L. and Richard M Ryan. 2014. Intrinsic Motivation and Self-Determination in Human Behavior. New York: Springer Science+Business Media.

Dewey, J. 1929. The Quest for Certainty. New York. https://psycnet.apa.org/record/1930-00008-000.

Dillenbourg, Pierre, Michael J. Baker, Agnès Blaye, and Claire O’Malley. 1995. "The Evolution of Research on Collaborative Learning." In Learning in Humans and Machine: Towards an Interdisciplinary Learning Science, 189-211. Elsevier, Oxford.

DoH. 2020. "COVID-19 Corona Virus South African Resource Portal." Government Information and Resource Website. SA Corona Virus Online Portal. March 12, 2020. https://sacoronavirus.co.za/information-about-the-virus-2/.

FLIP. 2014. "Definition of Flipped Learning." Flipped Learning Network Hub. https://flippedlearning.org/definition-of-flipped-learning/.

Fraga, Lucretia M. and Janis Harmon. 2014. "The Flipped Classroom Model of Learning in Higher Education: An Investigation of Preservice Teachers' Perspectives and Achievement." Journal of Digital Learning in Teacher Education 31(1): 18-27. https://doi.org/10.1080/ 21532974.2014.967420.

Gaughan, Judy E. 2014. "The Flipped Classroom in World History," 24.

Giannakos, Michail N., John Krogstie, and Trond Aalberg. 2016. "Video-Based Learning Ecosystem to 
Support Active Learning: Application to an Introductory Computer Science Course." Smart Learning Environments 3(1). https://doi.org/10.1186/s40561-016-0036-0.

Gilboy, Mary Beth, Scott Heinerichs, and Gina Pazzaglia. 2015. "Enhancing Student Engagement Using the Flipped Classroom." Journal of Nutrition Education and Behavior 47(1): 109-14. https://doi.org/10.1016/j.jneb.2014.08.008.

Gower, Primarashni. 2019. "Hybrid Learning - For the Classroom and beyond | University of Pretoria." University of Pretoria: News. 2019. https://www.up.ac.za/university-relations/news/ post_2807451-hybrid-learning-for-the-classroom-and-beyond.

Green, Lucy Santos, Jennifer R. Banas, and Ross A. Perkins, eds. 2017. The Flipped College Classroom. Educational Communications and Technology: Issues and Innovations. New York, NY: Springer Science and Business Media.

Heijstra, Thamar Melanie, and Margrét Sigrún Sigurðardóttir. 2018. "The Flipped Classroom: Does Viewing the Recordings Matter?" Active Learning in Higher Education 19(3): 211-23. https://doi.org/10.1177/1469787417723217.

Hein, George E. 1991. "Constructivist Learning Theory." http://www.exploratorium.edu/IFI/ resources/constructivistlearning.html.

Hodges, Tracey S. and Nancy Dubinski Weber. 2015. "Making Heads or Tails of Classroom Flipping." Kappa Delta Pi Record 51(2): 57-63. https://doi.org/10.1080/00228958.2015.1023135.

Hung, Cheng-Yu, Jerry Chih-Yuan Sun, and Jia-Yin Liu. 2019. "Effects of Flipped Classrooms Integrated with MOOCs and Game-Based Learning on the Learning Motivation and Outcomes of Students from Different Backgrounds." Interactive Learning Environments 27(8): 1028-46. https://doi.org/10.1080/10494820.2018.1481103.

Hwang, Gwo-Jen, Chengjiu Yin, and Hui-Chun Chu. 2019. "The Era of Flipped Learning: Promoting Active Learning and Higher Order Thinking with Innovative Flipped Learning Strategies and Supporting Systems." Interactive Learning Environments 27(8): 991-94. https://doi.org/ 10.1080/10494820.2019.1667150.

Kapp, Karl M. 2012. The Gamification of Learning and Instruction: Game-Based Methods and Strategies for Training and Education. John Wiley \& Sons.

Karabatak, Songül and Hakan Polat. 2019. "The Effects of the Flipped Classroom Model Designed According to the ARCS Motivation Strategies on the Students' Motivation and Academic Achievement Levels." Education and Information Technologies August. https://doi.org/10.1007/s10639-019-09985-1.

Kay, Robin, Thom MacDonald, and Maurice DiGiuseppe. 2019. "A Comparison of Lecture-Based, Active, and Flipped Classroom Teaching Approaches in Higher Education." Journal of Computing in Higher Education 31(3): 449-71. https://doi.org/10.1007/s12528-018-9197-x.

Keenge, Jared, and Grace Onchwari. 2016. Handbook of Research on Active Learning and the Flipped Classroom Model in the Digital Age. Advances in Educational Technologies and Instructional Design (AETID). IGI Global.

Kitchenham, Barbara. 2004. "Procedures for Performing Systematic Reviews." Keele University Technical Report TR/SE-0401 ISSN:1353-7776. https:/www.semanticscholar.org/paper/ Procedures-for-Performing-Systematic-Reviews-Kitchenham/29890a936639862f45cb9a987 dd599dce975 9bf5.

Kozinsky, Sieva. 2017. "How Generation Z Is Shaping the Change in Education." Forbes 2017. https://www.forbes.com/sites/sievakozinsky/2017/07/24/how-generation-z-is-shaping-thechange-in-education/.

Krathwohl, David R. 2002. "A Revision of Bloom's Taxonomy: An Overview." Theory into Practice 41(4). https://www.depauw.edu/files/resources/krathwohl.pdf.

Kupe, Tawana. 2020. “'We Must Find New Ways to Bridge the Digital Divide' - UP Vice-Chancellor on World Telecommunication and Information Society Day | University of Pretoria." University of Pretoria: News. May 17, 2020. https://www.up.ac.za/news/post_2895552-we-must-find-new- 
ways-to-bridge-the-digital-divide-up-vice-chancellor-on-world-telecommunication-andinformation-society-day-.

Landers, Richard N. 2014. "Developing a Theory of Gamified Learning: Linking Serious Games and Gamification of Learning." Simulation \& Gaming 45(6): 752-68. https://doi.org/10.1177/ 1046878114563660.

Li, Shen and Fang Dan. 2015. "Factors of College Students in the Flipped Classroom." In 2015 10th International Conference on Computer Science \& Education (ICCSE), 805-809. Cambridge, United Kingdom: IEEE. https://doi.org/10.1109/ICCSE.2015.7250355.

Lin, Li-Chun, I-Chun Hung, Kinshuk, and Nian-Shing Chen. 2019. "The Impact of Student Engagement on Learning Outcomes in a Cyber-Flipped Course." Educational Technology Research and Development 67(6): 1573-91. https://doi.org/10.1007/s11423-019-09698-9.

Liu, Connie K. W. 2019. "A Holistic Approach to Flipped Classroom: A Conceptual Framework Using e-Platform." International Journal of Engineering Business Management 11(January): 184797901985520. https://doi.org/10.1177/1847979019855205.

Long, Taotao, Joanne Logan, and Michael Waugh. 2016. "Students' Perceptions of the Value of Using Videos as a Pre-Class Learning Experience in the Flipped Classroom." TechTrends 60(3): 245252. https://doi.org/10.1007/s11528-016-0045-4.

Lopes, Sergio Francisco Sargo Ferreira, Luís Manuel Borges Gouveia, and Pedro Alexandre da Cunha Reis. 2019. "The Flipped Classroom and Higher Education - Experiences with Computer Science Students." International Journal of Advanced Engineering Research and Science 6(10): 13-18. https://doi.org/10.22161/ijaers.610.3.

May, Kaitlyn E. and Anastasia D. Elder. 2018. "Efficient, Helpful, or Distracting? A Literature Review of Media Multitasking in Relation to Academic Performance." International Journal of Educational Technology in Higher Education 15(1). https://doi.org/10.1186/s41239-018-0096-z.

O'Flaherty, Jacqueline and Craig Phillips. 2015. "The Use of Flipped Classrooms in Higher Education: A Scoping Review." The Internet and Higher Education 25(April): 85-95. https://doi.org/10.1016/j.iheduc.2015.02.002.

Olusegun, Steve. 2015. "Constructivism Learning Theory: A Paradigm for Teaching and Learning." IOSR Journal of Research \& Method in Education (IOSR-JRME) 6: 5. https://doi.org/ 10.9790/7388-05616670.

Özer, Hasan Huseyin, Sezer Kanbul, and Fezile Ozdamli. 2018. "Effects of the Gamification Supported Flipped Classroom Model on the Attitudes and Opinions Regarding Game-Coding Education." International Journal of Emerging Technologies in Learning (IJET) 13(01): 109. https://doi.org/10.3991/ijet.v13i01.7634.

Palazón-Herrera, José. 2018. "Effectiveness and Motivation towards the Use of Video Tutorials When Learning How to Use Music Software / Efectividad y Motivación Hacia El Uso de Videotutoriales Para El Aprendizaje de Un Software Musical." Cultura y Educación 30(4): 663-92. https://doi.org/10.1080/11356405.2018.1514804.

Palloff, Rena M. and Keith Pratt. 2013. Lessons from the Virtual Classroom. 2nd ed. Jossey-Bass: A Wiley Brand.

Pedrotti, Maxime, and Nicolae Nistor. 2019. "How Students Fail to Self-Regulate Their Online Learning Experience.” In Transforming Learning with Meaningful Technologies, ed. Maren Scheffel, Julien Broisin, Viktoria Pammer-Schindler, Andri Ioannou, and Jan Schneider, 11722:377-385. Cham: Springer International Publishing. https://doi.org/10.1007/978-3-030-29736-7_28.

Pellas, Nikolaos. 2018. "Is the Flipped Classroom Model for All? Correspondence Analysis from Trainee Instructional Media Designers." Education and Information Technologies 23(2): 757-75. https://doi.org/10.1007/s10639-017-9634-x.

Piaget, Jean. 1980. "The Psychogenesis of Knowledge and Its Epistemological Significance." In Language and Learning: The Debate Between Jean Piaget and Noam Chomsky, ed. Massimo Piattelli-Palmarini, 1-23. Harvard University Press. 
Reidsema, Carl, Lydia Kavanagh, Roger Hadgraft, and Neville Smith. (Ed.). 2017. The Flipped Classroom. New York, NY: Springer Berlin Heidelberg.

Richardson, Virginia. 2003. "Constructivist Pedagogy." Teachers College Record 105(9): 1623-40. https://doi.org/10.1046/j.1467-9620.2003.00303.x.

Robinson, Frank J., Philip M. Reeves, Helen Louise Caines, and Claudia De Grandi. 2020. "Using OpenSource Videos to Flip a First-Year College Physics Class." Journal of Science Education and Technology, February. https://doi.org/10.1007/s10956-020-09814-y.

Roehl, Amy, Shweta Linga Reddy, and Gayla Jett Shannon. 2013. "The Flipped Classroom: An Opportunity to Engage Millennial Students Through Active Learning Strategies." Journal of Family \& Consumer Sciences 105(2): 44-49. https://doi.org/10.14307/JFCS105.2.12.

Sari, Annisa R., Curtis J. Bonk, and Meina Zhu. 2020. "MOOC Instructor Designs and Challenges: What Can Be Learned from Existing MOOCs in Indonesia and Malaysia?" Asia Pacific Education Review 21(1): 143-66. https://doi.org/10.1007/s12564-019-09618-9.

Savage, Sam. 2006. "The Generation Z Connection: Teaching Information Literacy to the Newest Net Generation.” Redorbit. February 19, 2006. https://www.redorbit.com/news/technology/ 397034/the_generation_z_connection_teaching_information_literacy_to_the_newest/.

Schneider, Bertrand, and Paulo Blikstein. 2016. "Flipping the Flipped Classroom: A Study of the Effectiveness of Video Lectures Versus Constructivist Exploration Using Tangible User Interfaces." IEEE Transactions on Learning Technologies 9(1): 5-17. https://doi.org/10.1109/ TLT.2015.2448093.

Seedoyal-Seereekissoon, Denisha. 2018. "Flipped Classroom Teaching in Higher Education: An Assumption or an Inevitable Tool." People: International Journal of Social Sciences 4(1): 494506. https://doi.org/10.20319/pijss.2018.41.494506.

Selby, Cynthia C. 2015. "Relationships: Computational Thinking, Pedagogy of Programming, and Bloom's Taxonomy." In Proceedings of the Workshop in Primary and Secondary Computing Education on ZZZ - WiPSCE '15, 80-87. London, United Kingdom: ACM Press. https://doi.org/10.1145/2818314.2818315.

Sergis, Stylianos, Demetrios G. Sampson, and Lina Pelliccione. 2018. "Investigating the Impact of Flipped Classroom on Students' Learning Experiences: A Self-Determination Theory Approach." Computers in Human Behavior 78(January): 368-78. https://doi.org/10.1016/j.chb.2017.08.011.

Shnai, Iuliia. 2017. "Systematic Review of Challenges and Gaps in Flipped Classroom Implementation: Toward Future Model Enhancement," 7.

Shoba, Sandisiwe. 2020. “As South Africa Goes into Lockdown, Higher Education Department Prepares for Online Learning.” MSN 2020. https://www.msn.com/en-za/news/featured/as-south-africagoes-into-lockdown-higher-education-department-prepares-for-online-learning/ar-BB11EFSD.

Song, Min, Ying Song, and Zhengxian Wei. 2015. "A Teaching Model of Flipped Classroom Based on MOOC." In 2015 Eighth International Conference on Internet Computing for Science and Engineering (ICICSE), 269-72. Harbin, China: IEEE. https://doi.org/10.1109/ICICSE.2015.56.

Steen-Utheim, Anna Therese, and Njål Foldnes. 2018. "A Qualitative Investigation of Student Engagement in a Flipped Classroom." Teaching in Higher Education 23(3): 307-24. https://doi.org/10.1080/13562517.2017.1379481.

Sweller, John, Paul L. Ayres, and Slava Kalyuga. 2011. Cognitive Load Theory. Explorations in the Learning Sciences, Instructional Systems and Performance Technologies. New York: Springer.

Triantafyllou, Evangelia, and Olga Timcenko. 2015. "Out of Classroom Instruction in the Flipped Classroom: The Tough Task of Engaging the Students." In Learning and Collaboration Technologies, edited by Panayiotis Zaphiris and Andri Ioannou, 9192:714-23. Cham: Springer International Publishing. https://doi.org/10.1007/978-3-319-20609-7_67.

Tuna, Tayfun, Tuhin Dey, Jaspal Subhlok, and Leigh Leasure. 2017. "Video Supported Flipped Classroom," 13.

Turan, Zeynep, and H. Buluthan Cetintas. 2019. “Investigating University Students' Adoption of Video 
Lessons." Open Learning: The Journal of Open, Distance and e-Learning, November, 1-18. https://doi.org/10.1080/02680513.2019.1691518.

Vanderstraeten, Raf. 2002. "Dewey's Transactional Constructivism." Journal of Philosophy of Education 36(2): 233-46. https://doi.org/10.1111/1467-9752.00272.

Vygotski1̌, Lev Semenovich. 2012. Thought and Language. MIT Press.

Zainuddin, Zamzami, and Corinne Jacqueline Perera. 2017. "Exploring Students' Competence, Autonomy and Relatedness in the Flipped Classroom Pedagogical Model." Journal of Further and Higher Education August: 1-12. https://doi.org/10.1080/0309877X.2017.1356916. 